\title{
Family Background Risk Factors Associated with Domestic Violence among Married Thai Muslims Couples in Pattani Province
}

\author{
Kasetchai Laeheem ${ }^{1} \&$ Kettawa Boonprakarn ${ }^{1}$ \\ ${ }^{1}$ Faculty of Liberal Arts, Prince of Songkla University, Hatyai, Thailand \\ Correspondence: Kasetchai Laeheem, Faculty of Liberal Arts, Prince of Songkla University, Hatyai, Songkhla, \\ 90110, Thailand. E-mail: Lkasetchai@yahoo.com
}

Received: November 3, 2014

Accepted: December 3, 2014 Online Published: April 2, 2015

doi:10.5539/ass.v11n9p235

URL: http://dx.doi.org/10.5539/ass.v11n9p235

\begin{abstract}
This study examined family background risk factors associated with domestic violence among married Thai Muslim couples in Pattani Province. The informants were 1,536 wives who were representatives of their families. The $\mathrm{R}$ program was used for data analysis to determine the frequency, percentage, chi-square value, odds value, and logistic coefficient. The results were that 38.3 percent of the Thai Muslim couples in Pattani Province used domestic violence, and the risk factors of family background found to be associated with domestic violence at a significance level of .001 were four variables: strict upbringing, violent behavior in childhood, witnessing parents quarreling in childhood, and violent behavior in childhood. The married couples with chances to use domestic violence were as follows: those who witnessed their parents quarreling in childhood regularly (2.46 times); once in while (1.73 times); had severe punishment in their childhood regularly ( 0.65 times); once in a while ( 0.51 times); had very strict upbringing ( 0.53 times); had moderately strict upbringing ( 0.41 times); had violent behavior in childhood regularly ( 0.52 times); and once in a while ( 0.43 times), respectively. The results of this study would be beneficial in forming policy and taking preventive measures for children witnessing their parents quarreling in order to end the cycle of domestic violence.
\end{abstract}

Keywords: family background, risk factors, domestic violence, married Thai Muslim couples

\section{Introduction}

Presently, domestic violence has become a social problem that more organizations in the government and private sectors give importance to in order to prevent and solve because it has spread widely in every society and with married couples of all economic statuses, occupations, races, and religions. This hidden problem is complicated with an increasing degree of violence, which makes it more difficult to prevent and tackle (Kungsakon \& Pojam, 2008; Laeheem, 2014). This is different from the past when most people in Thai society did not give as much importance and realization to domestic violence as they should have because they thought that domestic violence was a personal problem specifically for family members only, and other people should not interfere or intervene (Pradabmuk, 2003; Kungsakon \& Pojam, 2008). Domestic violence between husbands and wives is mostly by husbands against their wives by intentionally using force to threaten or harm their wives physically or mentally such as forcing, threatening, beating, kicking, and limiting their freedom. These behaviors usually develop from conflicts and quarrels (Intarajit \& Karinchai, 1999; Triemchaisri, 2001; Laeheem, \& Boonprakarn, 2014). Domestic violence is the husband's abusive behavior against his wife with an intention to attack her physically and mentally by forcing and coercing her, and it is an action caused by anger, fright, anxiousness, and a lack of temperance, which sometimes can cause severe injuries or death (Walker, 2001; Malley-Morrison \& Hines, 2004; Hampton, Gullotta, \& Ramos, 2006; Kongsakon \& Pojam, 2008). Wives who are victims of domestic violence are usually wounded physically and mentally, and may decide to get a divorce. In addition, children who regularly witness such violence learn and absorb it in their memory and may feel that all problems can be solved with violence. This can make them violent when they are young as well as when they are grown up, and they may behave violently against their peers, spouse, and children (Promrak, 2007; Kungsakon \& Pojam, 2008; Laeheem, \& Boonprakarn, 2014). For the government sector, government organizations have to spend a large amount of money on campaigning through media to urge people to realize the violent problem, and help solve the problem. Furthermore, budget is needed to employ personnel related to providing treatment and consultations for victims of domestic violence (Hemmanad, 1990; Puawongpaet, 1994; Karnkanakul, 1997) 
According to a report by the Violence against Children and Women and Domestic Violence Information Center (2013), prevalence rates of domestic violence were still high during $2010-2013$. There were 949 incidents in 2010, 1065 in 2011, 887 in 2012, and 776 in 2013. The statistics on the number of children and women who came to the center for services showed that there were 22,639 violence incidents against women, of which 8,336 incidents or 36.82 percent were committed by people who were close to the victims or by family members, and 1 , 950 incidents or 8.61 percent by strangers. It was also found that most of the violence incidents against women (5,786 or 52.3 percent) were committed by their husbands (One Stop Crisis Center (OSCC), 2011). This resulted in divorces, and indicated that the rates of domestic violence incidents did not decrease, and most of them were done by family members, especially husbands against their wives. Moreover, in the past, the problem of domestic violence between husbands and wives had not been solved by related individuals and organizations because government officials and society regarded domestic violence as internal affairs between husbands and wives, personal conflicts, not crimes that affected other people, and therefore, other people should not interfere. If domestic violence cases were not very serious, police usually tried to settle them through reconciliations, and did not document the cases. As a result, individuals who committed the violence were not punished or were not punished suitably, and did not change their behaviors (Kungsakon \& Pojam, 2008; Laeheem, \& Boonprakarn, 2014).

There are many causal factors related to domestic violence, but one important cause is witnessing parents quarreling and hitting each other in childhood. Studies have found that there are a number of phenomena that reflect an increasing severity in violence against women by men who have experienced violence before their marriage (Kungsakon \& Pojam, 2008; Laeheem, \& Boonprakarn, 2014). Exposure to parents quarrelling during childhood was found to be the most important risk factor that resulted in married couples using violence in their own families (Ua-amnoey 2002; Parimutto, 2011). The problem of domestic violence stems from childhood experience, especially exposure to bad incidents including getting severe punishment in childhood, and witnessing parents' violent quarrels (Pongwech \& Wijitranon, 2000; Parimutto, 2011; Kongsakon \& Pojam, 2008). Husbands who commit violence against their wives are usually from families with domestic violence, and exposures to such incidents during their childhood have affected their feelings and emotions, so they learned and absorbed the violence that has become part of their personality and will remain there permanently. Consequently, they adopt the use of violence, and when they have conflicts, misunderstanding, and quarrels with their wives, they choose to use violence to solve their problems like what they experienced in their childhood. Obviously, experiences and exposures in childhood can contribute to the cycle of domestic violence because children will use violence in their own marriages when they grow up (Gelles \& Straus, 1979; Bandura, 1976).

In addition, more people with experiences in violence committed regularly by their parents against each other may display violence against their spouses than those who do not have such experiences (Stets, 1990; O'Leary \& Williams, 2006; Malley-Morrison \& Hines, 2007). Families, especially families that use violence to the extent that members think that it is part of their daily life, are sources of motivation for members to display violent behaviors towards people around them. Members of this type of family, in addition to thinking that violence is part of their daily life, adopt violence as an alternative for problem solving, and if they want respect from others, they use force and violence (Remschmidt, 1993; Brentro \& Long, 1995; Straus, 2001).

Thus, there is a need to investigate family background risk factors that are associated with domestic violence among Thai Muslim married couples in Pattani Province in order to determine whether and/or how the six variables of risk factors are associated with domestic violence. The eight variables are strict upbringing, democratic upbringing, negligent upbringing, severe punishment in childhood, exposure to parents' quarrels, violent behavior in childhood, females' inferior status, and the emphasis on patriarchy, or male dominance. The benefits of the results of this study will be for all related parties to use in preventing and providing help for married couples with domestic violence in addition to management of domestic violence in other provinces or regions before the problem becomes more serious with a higher degree of violence. The results of this study can help in finding ways to solve the problem of domestic violence that can become social problems in time.

\section{Literature Reviews}

Most domestic violence among married couples in Thai society is done by husbands on wives that calling "husband violence against his wives". Husband violence against his wives refers to husbands' behavioral patterns of hurting their wives physically, mentally and sexually in order to show power in controlling them. It also refers to assaulting wives by husband is one form of violence against his wives; it cuts off his wives' rights and obstructs the existence of sex equality and the development of peacefulness. (Phromrak, 2007; Parimutto, 2010; Supanichwatana \& Laeheem, 2017). It is an action that husband injures his wife that results in the victim's physical, mental and sexual injury or behavior that violates, forces, threatens, and injures each other. 
(Pichaisanith, 1997; Friends of Women Foundation, 2013). Husband violence against his wives refers to using force to harm physically, mentally, sexually or to harm life, and to violate rights and freedoms in various ways, which are unfair actions in order to get power to control over them or to make them yield. It is with a purpose to hurt his wives as well as to harm their health, rights, and freedoms. This is done by misuse of force or power to make his wives do or not do and accept the action (Pakjekwinyusakul, Jamsutee \& Nettayasupa, 2003; Punamsap, 2005; Ministry of Social Development and Human Security, 2007). Violence done to the wives can cause a lot of economic burden to society in terms of medical treatment, social welfare, counseling provision, and prevention measures, etc. Moreover, it affects them mentally and emotionally, and it affects children's learning and absorption of the feeling. Additionally, the victims (his wives) are not only injured physically but also psychologically which can remain in their memory all their life. (Puawongpaet, 1994; Kanjanakul, 1997; Promrak, 2007).

There are 5 causes of husband violence against his wives in Thai society; 1) Conflict of interest-Activities in a family can be a waste, and members of the family may want the opposite. That is, when one gains from doing one activity, the other might lose from doing it. Conflict can originate from different interest such as one member may want to go to a movie while another want to play sports. Conflict can also result from different characteristics such as one is messy but the other is tidy and has to clean up after him or her. 2) Childhood experiences of violence-Individuals' learning and absorption of violence from society and environments especially in childhood in a family that regularly uses violence, children can absorb violence and use it. They would see that violence is normal and believe that problems can be solved with violence. 3) Knowledge about life history of each other-Family members know life history of each other well such as ability, weak points, strong points, likes and dislikes, etc., which is different from members of other systems who know each other superficially. Therefore, conflict between family members can be more severe than that between members of other systems because they can attack the other exactly on his or her weak points or defects. 4) Social values and attitudes of surrounding people-Wrong beliefs about status with emphasis on male dominance that men must be heads of families and males' aggressiveness and violence are normal and macho. On the contrary, women must not be aggressive and violent because that is not what ladies should be. Good wives must be modest, humble, and patient, not haggle with their husbands, respect their husbands, obedient, and ready to serve their husband in all matters. Another belief is that husbands are owners of their wives and have rights to do anything with them even beating them for punishment, and their wives do not have the right to protest them. Moreover, other people should not interfere when husbands and wives quarrel because it is normal just like the tongue and teeth hitting each other. When fathers beat their children, they have the power to do it and other people should not pay attention to it. There is another belief that it is normal for married men to have sexual with other women but not for married women to do so because it is considered adultery, and such women are bad and nobody would want to be associated with. 5) In society without alertness to human rights that does not believe all human beings are equal in rights, it is normal for people in such society to see some people as having higher status and more rights than other people do. Women and children have a lower status than men have and thus have less rights, and this causes abuses against them and causes them to be taken advantage of. In society where violence is so widely used that it becomes normal and accepted, where the use of violent behaviors reflects advantage and becomes incentive for using more violence, and where environments have influence on violence, pressure, thought, people in such society will be aggressive and likely to commit more acts of violence. (Kaewfan, 2007; Parimutto, 2010; Daen-khunthod, 2011; Laeheem \& Boonprakarn, 2014).

\section{Methods}

\subsection{The Subjects}

The subjects of this study were 1,536 wives who were representatives of Thai Muslim married couples in Pattani Province in providing data. They were selected using multi stage sampling as follows. Stage 1) Districts were selected using stratified sampling divided into three strata which were districts with high and very high levels of population loss (red districts), districts with a moderate level of population loss (pink districts), and districts with a low level of population loss (green districts). These levels were determined using the data and trends of violence provided by the Deep South Watch (2013). Then two districts from each strata were selected using simple random sampling to get six districts. Stage 2) four sub-districts were selected from each district through simple random sampling to get 24 sub-districts. Stage 3) Two villages were selected from each sub-district to get 48 villages. Stage 4), the last stage of subjects selection, 32 wives were selected from each village to represent Thai Muslim married couples in Pattani Province in giving data. The 32 wives were then divided into two groups of 16. One group was with, and the other without, risk domestic violence behaviors. They were selected by local Muslim leaders in the target areas. 


\subsection{Research Instrument}

The research instrument was the Screening Inventory for Thai Muslim Spouses at Risk of Domestic Violence Behaviors (Laeheem, 2014) that was developed by the researcher, and has been tested for its quality and to be with normal criteria for results interpretation. The five rating scales are: $4=$ Regularly ( 16 times or more); $3=$ Often $(11-15$ times); $2=$ Quite often $(6-10$ times $) ; 1=$ Once in a while $(1-5$ times $)$; and $0=$ Never. (Laeheem \& Sungkharat, 2012). The target group was asked to determine the level of their spouse's behaviors during the last six months. (See appendix).

\subsection{Data Collection}

The data for this study were collected through via face-to-face interview by the researcher and research assistants who, even though, were with experiences in data collection and were locals of the target areas, were retrained in order to have the same data collecting methods.

\subsection{Variables Used in the Research}

There were eight determinants which were strict upbringing, democratic upbringing, negligent upbringing, severe punishment in childhood, exposure to parents' quarrels, violent behavior in childhood, females' inferior status, and the emphasis on patriarchy, or male dominance, and the outcome was domestic violence.

\subsection{Data Analysis}

The $\mathrm{R}$ program, $\mathrm{R}$ commander package, and epicalc package were used to analyze descriptive data to calculate the frequencies and percentages. Chi-square test was used to analyze the relationship between family background factors and domestic violence, and family background risk factors associated with domestic violence were analyzed by computing logistic coefficients and the odds ratios.

\subsection{Variable Measurement}

1. The eight variables of determinants were measured by finding means of the questionnaire and making them into standard scores or z-scores. After that they were divided into three groups where the cut points were set as follows. If the standard score was lower than -1.00 , it meant that it was at a low level or never. If the standard score was from 1-.00 to 1.00, it meant that it was at a moderate level or once in a while, and if the standard score was from 1.01 or more, it meant that it was at a high level or regularly.

2. Criterion variables were calculated by adding up the results of the measurement form and comparing them against the normal criteria of the screening inventory developed by the researcher. The criterion is that Thai Muslim married couples who are classified into the group with domestic violence were those whose score is from 118 or more (T56.15 or more).

\section{Results}

\subsection{General Data on Family Background Risk Factors in Eight Variables and Domestic Violence}

The data were collected from the 1,536 wives who were representatives of Thai Muslim married couples in Pattani Province in giving data. It was found that most of them (42.1\%) were raised in a strict upbringing style at a moderate level, followed by those who were raised this way at a high level (29.7\%), and a low level (28.2\%), respectively. Most of the subjects $37.6 \%$, were raised in a democratic upbringing style at a high level, followed by those who were raised in this style at a low level (31.4\%), and at a moderate level (31.4\%). Most of the subjects $(45.2 \%)$ were raised with a negligent upbringing style at a high level, followed by those who were raised in this style at a low level, and a moderate level were (31.4\%), and (23.4\%), respectively. In addition, most of the subjects (38.4\%) had severe punishment in childhood once in a while, followed by those who had severe punishment regularly (33.5\%), and those who never had it (28.1\%). The percentage of the subjects who witnessed their parents' quarrels in their childhood once in a while, and that of those who never witnessed such incidents were the same $(39.8 \%)$; those who regularly witnessed the incidents, and those who had violent behaviors in childhood once in a while were of the same percentage of $44.9 \%$, followed by those who never had violent behaviors in childhood (38.4\%), and regularly had such behaviors (16.7\%), respectively. Most of the subjects (37.7\%) thought that they had an inferior status at a moderate level, followed by those who thought they had an inferior status at a high level (33.7\%), and at low level (28.6\%), respectively. The percentages of the subjects who believed in male dominance at a low level, and a high level were almost the same $(37.4 \%$ and $37.2 \%$ ), and at a moderate level (25.4\%). Five hundred and eighty-nine (589), or 38.3 percent of Thai Muslim married couples in Pattani Province were classified into a group with violent behaviors, 947 or 61.7 percent of them were classified into the group without violent behaviors. 


\subsection{The Association between the Eight Variables of Family Background Risk Factors and Domestic Violence}

Analysis was performed to find out about the association between domestic violence in the Thai Muslim married couples in Pattani Province and the eight variables of family background risk factors which were strict upbringing, democratic upbringing, negligent upbringing, severe punishment in childhood, exposure to parents' quarrels, violent behavior in childhood, females' inferior status, and the emphasis on patriarchy, or male dominance. The analysis using a chi-square test found that strict upbringing and violent behavior in childhood had a statistically significant associated with domestic violence at .001, and severe punishment in childhood and exposure to parents' quarrels had a statistically significant associated with domestic violence at .01 . Democratic upbringing, negligent upbringing, females' inferior status, and the emphasis on patriarchy, or male dominance did not have a statistically significant associated with domestic violence. Thai Muslim married couples in Pattani Province who had a high proportion of domestic violence were those who had strict upbringing at a high level, regularly had severe punishment in childhood, were regularly exposed to parents' quarrels, and regularly had violent behaviors. (See Table 1)

Table 1. Association between family background risk factors and domestic violence

\begin{tabular}{|c|c|c|c|c|c|}
\hline \multirow[b]{2}{*}{ Determinants } & \multicolumn{3}{|c|}{ Domestic violent } & \multirow[b]{2}{*}{ Chi-square } & \multirow[b]{2}{*}{$p$-value } \\
\hline & $\begin{array}{c}\text { Not violent } \\
(947)\end{array}$ & $\begin{array}{l}\text { Violent } \\
(589)\end{array}$ & $\begin{array}{c}\text { Total } \\
(1,536)\end{array}$ & & \\
\hline Strict upbringing & & & & 27.564 & 0.000 \\
\hline Low & 68.2 & 31.8 & 28.2 & & \\
\hline Moderate & 64.1 & 35.9 & 42.1 & & \\
\hline High & 52.0 & 48.0 & 29.7 & & \\
\hline Democratic upbringing & & & & 3.766 & 0.152 \\
\hline Low & 60.7 & 39.3 & 31.4 & & \\
\hline Moderate & 59.0 & 41.0 & 31.0 & & \\
\hline High & 64.6 & 35.4 & 37.6 & & \\
\hline Negligent upbringing & & & & 1.350 & 0.509 \\
\hline Low & 61.8 & 38.2 & 31.4 & & \\
\hline Moderate & 59.2 & 40.8 & 23.4 & & \\
\hline High & 62.8 & 37.2 & 45.2 & & \\
\hline Severe punishment in childhood & & & & 11.974 & 0.003 \\
\hline Never & 68.2 & 31.8 & 28.1 & & \\
\hline Once in a while & 60.5 & 39.5 & 38.4 & & \\
\hline Regularly & 57.5 & 42.5 & 33.5 & & \\
\hline Exposure to parents' quarrels & & & & 9.280 & 0.009 \\
\hline Never & 68.8 & 31.2 & 39.8 & & \\
\hline Once in a while & 61.0 & 39.0 & 39.8 & & \\
\hline Regularly & 58.6 & 41.4 & 20.4 & & \\
\hline Violent behavior in childhood & & & & 34.923 & 0.000 \\
\hline Never & 69.3 & 30.7 & 38.4 & & \\
\hline Once in a while & 60.1 & 39.9 & 44.9 & & \\
\hline Regularly & 48.2 & 51.8 & 16.7 & & \\
\hline Females' inferior status & & & & 1.795 & 0.408 \\
\hline Low & 59.1 & 40.9 & 28.6 & & \\
\hline Moderate & 62.3 & 37.7 & 37.7 & & \\
\hline High & 63.1 & 36.9 & 33.7 & & \\
\hline The emphasis on patriarchy & & & & 3.101 & 0.212 \\
\hline Low & 60.8 & 39.2 & 37.4 & & \\
\hline Moderate & 59.0 & 41.0 & 25.4 & & \\
\hline High & 64.3 & 35.7 & 37.2 & & \\
\hline
\end{tabular}

\subsection{Family Background Risk Factors Associated with Domestic Violence}

In analyzing family background risk factors associated with domestic violence in the Thai Muslim married couples in Pattani Province using binary logistic regression, four variables were found to be significantly associated with domestic violence. They were strict upbringing, severe punishment in childhood, exposure to 
parents' quarrels, and violent behavior in childhood ( $p$ value $<.001$ ) with a residual deviance of 954.4 on 1527 degrees of freedom. Married couples who had strict upbringing at a high level and a moderate level had a higher probability of having domestic violence than those who had this upbringing style at a low level at 0.53 times $(95 \%$ C.I. $0.41-0.69)$, and 0.41 times (95\% C.I. $0.28-0.89$ ), respectively. Married couples who regularly had severe punishment in childhood had a higher chance 0.65 times $(95 \%$ C.I. $0.50-0.85)$, and those who had it once in a while had a higher chance 0.51 times $(95 \%$ C.I. $0.36-0.71)$ than those who never had severe punishment in childhood to have domestic violence. Married couples who regularly, and who, once in a while, were exposed to parents' quarrels had a higher chance to have domestic violence than those who were never exposed to parents' quarrels 2.46 times (95\% C.I. 1.74 - 3.49) and 1.73 times (95\% C.I. 1.27 - 2.36), respectively. Married couples who regularly had violent behaviors in childhood had a higher chance 0.52 times (95\% C.I. 0.37 - 0.72 ), and those who had such behaviors once in a while had a higher chance 0.43 times $(95 \%$ C.I. $0.31-0.61)$ than those who never had violent behaviors in childhood of having domestic violence. (See Table 2)

Table 2. Family background risk factors associated with domestic violence, final model

\begin{tabular}{|c|c|c|c|c|c|}
\hline Factors & Odds ratio & $\begin{array}{l}95 \% \text { Confidence } \\
\text { interval (C.I.) }\end{array}$ & S.E. & Wald & $p$-value \\
\hline Strict upbringing & & & & 30.088 & 0.000 \\
\hline Low & 1 & & & & \\
\hline Moderate & 0.41 & $0.28,0.59$ & 0.19 & 23.114 & 0.000 \\
\hline High & 0.53 & $0.41,0.69$ & 0.14 & 22.038 & 0.000 \\
\hline Severe punishment in childhood & & & & 18.022 & 0.000 \\
\hline Never & 1 & & & & \\
\hline Once in a while & 0.51 & $0.36,0.71$ & 0.17 & 15.388 & 0.000 \\
\hline Regularly & 0.65 & $0.50,0.85$ & 0.14 & 9.608 & 0.002 \\
\hline Exposure to parents' quarrels & & & & 25.577 & 0.000 \\
\hline Never & 1 & & & & \\
\hline Once in a while & 1.73 & $1.27,2.36$ & 0.16 & 12.200 & 0.000 \\
\hline Regularly & 2.46 & $1.74,3.49$ & 0.18 & 25.535 & 0.000 \\
\hline Violent behavior in childhood & & & & 25.363 & 0.000 \\
\hline Never & 1 & & & & \\
\hline Once in a while & 0.43 & $0.31,0.61$ & 0.17 & 23.785 & 0.000 \\
\hline Regularly & 0.52 & $0.37,0.72$ & 0.17 & 15.183 & 0.000 \\
\hline
\end{tabular}

\section{Discussion and Conclusions}

The results of the study revealed that family background risk factors significantly associated with domestic violence among Thai Muslim married couples were four variables: strict upbringing, severe punishment in childhood, exposure to parents' quarrels, and violent behaviors in childhood. Married couples who had a high chance of having domestic violence were those who were exposed to parents' quarrels regularly (2.46 times), once in a while (1.73 times), those who had severe punishment in childhood regularly ( 0.65 times), and once in a while (0.51 times). Married couples who had strict upbringing at a high level (0.53 times), at a moderate level (0.41 times), those who regularly had violent behaviors in childhood ( 0.52 times), and those who, one in a while, had violent behaviors in childhood ( 0.43 times). The results of the study indicate that family background risk factors that are most associated with domestic violence among Thai Muslim married couples are: regular exposure to parents' quarrels (2.46 times) and occasional exposure to parents' quarrels (1.73 times). This is because witnessing parents' quarrels in childhood enables children's learning process and response through imitation. Human's learning is more efficient and more effective in the context where there is feeling and emotion which often takes place during childhood when children are ready to learn and imitate their parents more than other people, and thus children learn and absorb what they learn into their personality and remain with them until they grow up. When children learn and experience violence committed by people in the family, they lean the norm and adopt violence as well as the role model of using violence. Therefore, when they grow up and have conflicts with their spouse, they imitate their parents' behavior and use violence in solving the problem (Gelles \& Straus, 1979; Bandura, 1976).

Additionally, children who experience violence in their family, especially from exposure to parents' quarrels, can absorb and imitate such violence which can lead to a norm of using violence and will use violence against their spouses when they are married, and the violence will continue in a cycle (Gelles \& Straus, 1979; Bandura, 
1986). In a study by O'Leary \& Williams (2006), it was found that individuals who have frequently experienced family violence such as parents beating and scolding each other, parents beating their children, and sibling quarrels, are more likely to use violence against their spouses than those who have not had such experiences. This corresponds with a result of a study by Stets (1990) who found that people who have experienced violence have a higher chance of displaying violence against their spouses than those who have not. Children who have experienced violence between their parents have higher chances of committing violence than those who have not, 4.50 times (Laeheem, Kuning, McNeil, \& Besag, 2008); 7.60 times (Laeheem, Kuning, \& McNeil, 2009), and 7.11 times (Laeheem, Kuning, \& McNeil, 2010). Children who have experiences in exposure to family violence, particularly, parents' quarrels, and severe punishments in childhood can absorb and imitate such violence (Laeheem, 2013a). Youth who have seen their parents quarrel have a higher chance (1.47 times) of committing violence than those who have not (Laeheem \& Baka, 2009). Youth who have violent behaviors are usually from families with domestic violence such as beating and physically hurting each other, which is one of important causes of domestic violence because these children absorb and imitate what they have seen and think that violence can solve problems (Laeheem \& Baka, 2012). Moreover, one risk factor that leads to violence and offenses is witnessing violent or illegal actions by others (Malley-Morrison \& Hines, 2007).

As can be seen, influence of violence reinforces negative life experiences and is a starting point of violent behaviors, and encourages individuals to display violent behaviors that they have seen or experienced which make them feel that such behaviors are normal part of daily life. Experiences in violence motivate individuals to follow, and they are more motivated when repeatedly experience such violence, and try to justify or adopt violence as a method of problem solving. Individuals, especially youth, whose families often quarrel and have conflicts can be seriously stressed because of the harmful environments, and if serious stress happens for a long time, they usually go against adults and think that when people want to be respected, they have to use force and violence (Brentro \& Long, 1995; Straus, 2001). Families are one cause of increasing violent behaviors, particularly, families with domestic violence, which motivates violent behaviors, and motivates individuals to show violent behaviors or accept that violent behaviors are normal for daily living, and that violence is an alternative for solving problems (Remschmidt, 1993; Laeheem, 2013b). Unsuitable transfer of knowledge, principles of practice, attitudes, and values are processes that make individuals unable to live in society happily, and results in conflict, quarrels, and physical assaults, which can be so serious that they eventually become domestic violence (McCall \& Simmons, 1982; Hemmanad, 1990; Pongwech \& Wijitranon, 2000; Parimutto, 2011).

The results of the study are beneficial for seeking ways to prevent and reduce domestic violence. However, parents and guardians must have realization and give importance to their children's feelings, be patient, forgive, understand, trust, and avoid quarrels so that children will not lean, absorb, and imitate violence, and use it against their spouses when they grow up and are married. In addition, relatives and related organizations must cooperate to campaign against domestic violence, and must cooperate with religious leaders and local leaders to promote happy and peaceful family, and encourage married couples to lead their married life in a desirable way according to the social norm and as expected by Muslim society specified in the Islamic principles.

\section{Acknowledgements}

I would like to thank the Research Fund, Faculty of Liberal Arts, Prince of Songkla University for its financial support.

\section{References}

Bandura, A. (1976). Social learning analysis of aggression. In E. Ribesynes, \& A. Bandura (Eds.), Analysis of delinquency and aggression (pp. 203-212). Hillsdale, NJ: Earlbaum.

Bandura, A. (1986). Social foundations of thought and action: A social cognitive theory. Englewood Cliffs, NJ: Prentice-Hall.

Brentro, L., \& Long, N. (1995). Breaking the cycle of conflict. Educational Leadership, 2, 52-56.

Center of Deep South Watch. (2013). The data and trends of the situation severity in the South. Pattani: Center of Deep South Watch.

Daen-khunthod, C. (2011). Domestic violence: A study of wives being assaulted by husbands in Nakhon Ratchasima (Unpublished master's thesis). Rajabhat Nakhon Ratchasima University, Nakhon Ratchasima.

Friends of Women Foundation. (2013). Situations of domestic violence in the year 2012. Bangkok: Friends of Women Foundation. 
Gelles, R. J., \& Straus R. A. (1979). Determinants of violence in the family: Toward a theoretical integration. In W. R. Burr, R. Hill, F. I. Nye, \& I. L Reiss (Eds.), Contemporary theories about the family (pp. 549-581). New York: Free Press.

Hampton, R. L., Gullotta, T. P., \& Ramos, J. M. (2006). Interpersonal violence in the African American community: Evidence-based prevention and treatment practices. New York: Springer. http://dx.doi.org/10.1007/978-0-387-29598-5

Hemmanad, H. (1990). Family violence: The case of study low income husbands in municipal areas Muang district, Ubonratchathani province (Unpublished master's thesis). Thammasart University, Bangkok.

Intarajit, I., \& Karinchai, N. (1999). Women and children: The victim of domestic violence. Bangkok: Institute of Psychology Hot Line.

Kaewfan, K. (2007). Domestic violence: a case study of woman labor in factories in Saraphi District, Chiang Mai and violence against spouses (Unpublished master's thesis). Chiang Mai University, Chiang Mai.

Kanjanakul, C. (1997). A domestic violence: A study of wife battering (Unpublished doctoral's dissertation). Srinakharinwirot University, Bangkok.

Kongsakon, R., \& Pojam, N. (2008). Family violence. Bangkok: Srinakharinwirot University.

Laeheem, K., \& Sungkharat, U. (2012). Development of screening inventory for students at risk of exposure to bullying behavior in Islamic private schools, Songkhla province. Kasetsart Journal of Social Sciences, 33(2), 175-187.

Laeheem, K. (2013a). Factors associated with bullying behavior in Islamic private schools, Pattani province, southern Thailand. Asian Social Science, 9(3), 55-60. http://dx.doi.org/10.5539/ass.v9n3p55

Laeheem, K. (2013b). Family and upbringing background of students with bullying behavior in Islamic private schools, Pattani province, Southern Thailand. Asian Social Sciences, 9(7), 162-172. http://dx.doi.org/10.5539/ass.v9n7p162

Laeheem, K. (2014). Development of screening inventory for Thai Muslim spouses at risk of domestic violence behaviors in Satun province. Asian Social Sciences, 10(10), 138-144. http://dx.doi.org/10.5539/ass.v10n14 p138

Laeheem, K., \& Baka, D. (2012). A study of Thai youth's violent behaviour in the three southern border provinces of Thailand. NIDA Development Journal, 52(1), 159-187.

Laeheem, K., \& Boonprakarn, K. (2014). Domestic violence behaviors between spouses in Thailand. Asian Social Sciences, 10(16), 152-159. http://dx.doi.org/10.5539/ass.v10n16p152

Laeheem, K., \& Baka, D. (2009). Risk factors related to youths' violence behaviors in the three southern border provinces of Thailand. Songklanakarin Journal of Social Sciences and Humanities, 15(6), 897-911.

Laeheem, K., Kuning, M., \& McNeil, N. (2009). Bullying: Risk factors becoming 'Bullies'. Asian Social Science, 5(5), 50-57. http://dx.doi.org/10.5539/ass.v5n5p50

Laeheem, K., Kuning, M., \& McNeil, N. (2010). Bullying: The identify technique and its major risk factors. In Proceeding of the 2nd international conference on humanities and social sciences, 10 April, 2010. (pp. 31-42). Songkhla: Prince of Songkla University.

Laeheem, K., Kuning, M., McNeil, N., \& Besag, V. E. (2008). Bullying in Pattani primary schools in Southern Thailand. Child: Care Health and Development, 35(2), 178-183. http://dx.doi.org/10.1111/j.1365-2214. 2008.00890.x

Malley-Morrison, K., \& Hines, D. A. (2004). Family violence in a cultural perspective: Defining, understanding, and combating abuse. Thousand Oaks, CA: Sage Publications.

Malley-Morrison, K., \& Hines, D. A. (2007). Attending to the role of race/ethnicity in family violence research. Journal of Interpersonal Violence, 22, 943-972. http://dx.doi.org/10.1177/0886260507303060

McCall, G. J., \& Simmons, J. L. (1982). Social psychology: A sociological approach. New York: The free Press.

Ministry of Social Development and Human Security. (2007). Protection victim statute with domestic violence 2007. Bangkok: Ministry of Social Development and Human Security.

O'Leary, K. D., \& Williams, M. C. (2006). Agreement about acts of aggression in marriage. Journal of Family Psychology, 20, 656-662. http://dx.doi.org/10.1037/0893-3200.20.4.656 
One Stop Crisis Center (OSCC). (2011). Statistics of women and children seeking asylum at OSCC. Bangkok: OSCC.

Pakjekwinyusakul, W., Jamsutee, U., \& Nettayasupa, A. (2003). Evaluation of the judicial proceedings response to family violence. Bangkok: Pim-aksorn.

Parimutto, A. (2011). Family conflict solution applied from Theravāda Buddhism Dhamma (Unpublished master's thesis). Mahachulalongkornrajavidyalaya University, Bangkok.

Pichaisanith, P. (1997). Family development. Bankok: Ammarin Printing and Publishing.

Pongwech, M., \& Wijitranon, S. (2000). Dissection stalemate: Gender and domestic violence. Bankok: Gender and Development Research Institute.

Pradabmuk, P. (2003). Family violence: State of the art review and research promoting system in the future. Nontaburi: Health Systems Research Institute.

Promrak, T. (2007). Women and domestic violence: Divorce as the solution (Unpublished master's thesis). Thammasart University, Bangkok.

Puawongpaet, S. (1994). Thai family: The problems and solutions. Journal of Public Welfare, 37(6), 20-24.

Punamsap, W. (2005). Problems and solutions of domestic violence (Unpublished master's thesis). Krirk University, Bangkok.

Remschmidt, H. (1993). Cycle of Violence. Deutsches Aerzteblatt, 39, 35-40.

Stets J. (1990). Verbal and physical aggression in marriage. Journal of Marriage and the Family, 5, 501-514. http://dx.doi.org/10.2307/353043

Straus, S. (2001). Contested meanings and conflicting imperatives: A conceptual analysis of genocide. Journal of Genocide Research, 3(3), 349-375. http://dx.doi.org/10.1080/14623520120097189

Supanichwatana, S., \& Laeheem, K. (2017). Violence against Spouses in Thailand (pp. 13-18). In $6^{\text {th }}$ International Conference on Humanities and Social Sciences. Faculty of Defence Studies and Management, National Defence University of Malaysia in conjunction with Faculty of Liberal Arts, Prince of Songkla University.

Triemchaisri, S. (2001) Violence against women: The effects of violence and its prevention. The Journal of Nursing Science, 50(1), 8-15.

Ua-amnoey, J. (2002). Restorative justice: Relief to domestic violence. Bangkok: Chulalongkorn University.

Violence against Children and Women and Domestic Violence Information Center. (2013). Annual report on domestic violence cases. Retrieved December 9, 2013, from http://www.violence.in.th/violence/report/ violence/report001.aspx

Walker, P. L. (2001). A bioarchaeological perspective on the history of violence. Annual Review of Anthropology, 30, 573-596. http://dx.doi.org/10.1146/annurev.anthro.30.1.573

\section{Appendix}

Screening Inventory for Thai Muslim Spouses at Risk of Domestic Violence Behaviors (Laeheem, 2014).

Explanation Please asked the target group to determine the level of their spouse's behaviors during the last six months. The criterion for the score of each level is as follows.

$$
\begin{array}{llll}
4 & \text { means } & \text { the target group has regularly been abused with that behavior. } & \text { (16 times or more) } \\
3 & \text { means } & \text { the target group has often been abused with that behavior. } & (11-15 \text { times }) \\
2 & \text { means } & \text { the target group has quite often been abused with that behavior. } & (6-10 \text { times }) \\
1 & \text { means } & \text { the target group has once in a while been abused with that behavior. } & \text { (1-5 times) } \\
0 & \text { means } & \text { the target group has never been abused with that behavior. } &
\end{array}
$$

\begin{tabular}{l|c|c|c|c|c}
\hline \multirow{2}{*}{ Domestic Violence Behaviors } & \multicolumn{4}{|c}{ Behaviors level } \\
\cline { 2 - 5 } & 4 & 3 & 2 & 1 & 0 \\
\hline Aspect 1: Physical abuse & & & & & \\
\hline Kicked & & & & & \\
\hline Hit & & & & & \\
\hline
\end{tabular}




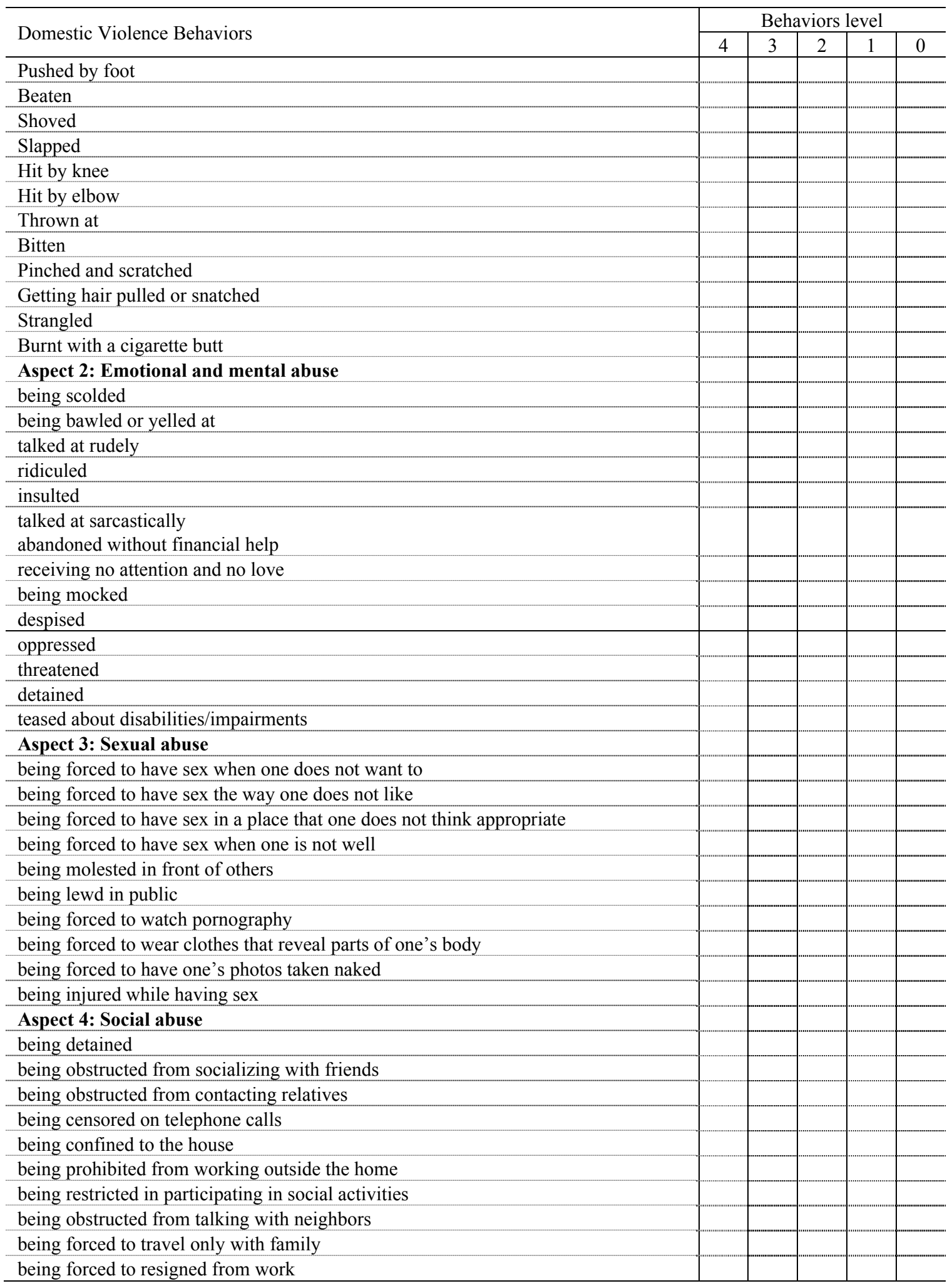

\section{Copyrights}

Copyright for this article is retained by the author(s), with first publication rights granted to the journal.

This is an open-access article distributed under the terms and conditions of the Creative Commons Attribution license (http://creativecommons.org/licenses/by/3.0/). 